\title{
Ontstaan en eerste periode van die Hervormde teologiese opleiding aan die Universiteit van Pretoria
}

\author{
JA Loader \\ Universiteit van Suid-Afrika
}

\begin{abstract}
Establishment and first period of the Hervormde theological training at the University of Pretoria

In this study the establishment of the Hervormde theological training at the University of Pretoria is researched with the purpose of identifying the ecclesiastical, religious and theological factors that influenced the emergence and development of a typical Hervormde type of theology in South Africa. It is argued that the resistance of the Transvaal Afrikaners to religious encroachment of their independence in the Boer Republic of the nineteenth century caused distrust of the church and theology associated with Stellenbosch in the British Cape Colony, and that opposition to trends from there determined the association of the Transvaal Hervormers with certain Dutch circles. From the joining of these two forces - what the Transvaal Hervormers required and what the contemporary Dutch theologies could offer - sprang the roots of what Hervormde theology came to be.
\end{abstract}

In hierdie oorsig sal ons die eerste klanke ten gunste van 'n eie Hervormde teologiese opleiding plaas in die konteks van die bewoë Transvaalse kerkgekiedenis van die tagtiger-en negentigerjare, en daarna die verloop van die verdere ontwikkelinge volg tot by die oprigting van die teologiese opleiding in 1917. Die Driejarige Oorlog van 1899-1902 maak 'n natuurlike waterskeiding uit en dienooreenkomstig sal ons oorsig ook in twee dele uiteenval - rofweg in die anderhalwe dekade vóor en die anderhalwe dekade ná die Driejarige Oorlog, wat strek van die 
kerkvereniging in $1885 / 6$ tot die totstandkoming van die teologiese opleiding in Pretoria in 1917.

\section{DIE ANDERHALWE DEKADE VOOR DIE DRIEJARIGE OORLOG}

Ons sal hier konsentreer op die Algemene Kerkvergadering van 1890 en die agtergronde daarvan, en daarna aandag gee aan die ontwikkelinge tydens die daaropvolgende Algemene Kerkvergaderings.

\subsection{Die Algemene Kerkvergadering van 1890 in die lig van die kerkvereniging.}

Dit word gewoonlik aanvaar dat die eerste klanke ten gunste van 'n eie teologiese opleiding vir die Nederduitsch Hervormde Kerk van Afrika dié was wat op 28 April 1890 in 'n brief in De Volksstem uitgespreek is. Die anonieme brief is waarskynlik geskryf deur diaken MJ Willemse van Roossenekal en bepleit die plaaslike opleiding van 'onze staatszonen' vir die predikantsamp (die teks van die brief is te vinde in Engelbrecht 1927: 196-197). Hiervoor het teologiese of ideologiese gronde nie die beweegrede uitgemaak nie, maar wel ekonomiese oorwegings: Die koste van studie in Nederland is te hoog en, tweedens, die predikante wat in Nederland opgelei is, sal 'voor geen klein salaris' in die ZAR wil werk nie. Ironies genoeg was dit juis ekonomiese oorwegings wat die uitvoering van hierdie desideratum lank sou kortwiek terwyl teologiese en ideologiese oorwegings in die latere bepleiting van 'n eie opleiding nie ontbreek het nie.

Op die Algemene Kerkvergadering van daardie jaar het diaken Willemse dieselfde gedagte oor die opleiding van 'eenige van onze landszonen' as beskrywingspunt ingedien (Notule, bl 19), maar die vergadering was slegs bereid om kerkrade op die 'uitnemende gelegenheid' van studie in Nederland en die daarvoor beskikbare beurse op die hart te druk. Op hierdie vergadering het daar egter ander oorwegings as die koste van die opleiding na vore gekom. Twee pole kan bespeur word in die bydrae van die voorsitter, ds MJ Goddefroy, wat van hier af prominent in die geskiedenis na vore tree. Ek sal dit probeer uitwys en teen die agtergrond van die destydse kerkpolitieke situasie probeer verklaar. Dan sal ons die bestaan van die twee elemente naas mekaar as 'n werkshipotese gebruik en aan die verdere verloop van die geskiedenis toets.

Goddefroy het beklemtoon dat 'n kweekskool nie vir die Hervormde Kerk aanvaarbaar is nie: 'Wij moeten een Hoogeschool hebben - geen Kweekschool' (Notule, bl 20). Dus: universitêre opleiding en nie suiwer kerklike opleiding nie. Dit moet as opposisie teen die destydse opleiding in Stellenbosch gesien word aangesien, veral ná die kerkvereniging van 1886, die opleiding van die Kaapse Kerk as 'n 
onaanvaarbare proposisie vir Hervormers beskou is. Hierdie klem op universitêre onderwys is nooit deur die Kerk laat vaar nie, selfs nie toe besluit is om by gebrek aan 'n universiteit tog maar 'n kweekskool op te rig nie (sien hieronder). Waarskynlik is die Kerk in hierdie opvatting gesterk deur die feit dat die vooruitsig van 'n eie universiteit reeds in 1889 in die Volksraad te berde gebring is. In hierdie stadium het die kerkpolitieke oorweging waarskynlik nog 'n groot rol gespeel, hoewel teologiese oorwegings nie ontbreek het nie. Die kerkpolitiek had natuurlik ook 'n politieke aspek, soos ons nog sal sien. Hier kan ons egter reeds let op die kombinasie van kerkpolitiek en politiek in die optrede van ouderling CJ Joubert op die vergadering. Hy het sonder meer verklaar (Notule, bl 16) dat in die naam 'Hervormd', dus in die handhawing van die Hervormde tradisie, 'voor ons een waarborg ligt, zoowel geestelijk als politiek'. Hierdie uitspraak was in ooreenstemming met sy opvattinge van vroeër, ná die kerkvereniging (sien hieronder). Die antagonisme teen Stellenbosch, wat eweneens 'n kenmerk van die Hervormde gevoelens sou bly, is tekenend op hierdie vergadering uitgespreek deur ouderling JD Weilbach van Heidelberg, wat verklaar het dat hy eerder wil sien dat sy seuns boere word as predikante, 'want ik ben te bang dat die Stellenbossche geest er in zal komen' (Notule, bl 20).

Goddefroy het studie in Nederland bepleit ten spyte van die 'modernen' wat aan die teologiese fakulteite aldaar verbonde was. Volgens hom was alleen Leiden nog gedeeltelik 'n modernistiese gevaar. 'Modernen' was na sy mening ook in die Kaapse Kerk te vind, en 'een modern leeraar hoort in de Ned Herv Kerk niet thuis'. Dus: Die klem op 'n breë kulturele universiteitsopleiding het van die begin af gepaard gegaan met teenkanting teen teologiese liberalisme of vrysinnigheid. Die beskuldiging van liberalisme (in die destydse konteks sinoniem met vrysinnigheid of modernisme) in die Hervormde teologie van daardie tyd hou daarom nie steek nie. Nie in die Hervormde Kerk met sy begeerte na 'n breë universiteitsopleiding nie, maar in die Kaapse Kerk met sy behoudende kweekskool en al was moderniste te vinde (Goddefroy het darem toegegee dat Stellenbosch nie hiervoor verantwoordelik was nie).

Die kombinasie van hierdie twee elemente, 'n breë kulturele visie op die opleiding en 'n gebondenheid aan die regsinnigheid, het 'n kenmerk gebly van die Hervormde teologiese oriëntering. Ons vind dit reeds in die kiem by die eerste Algemene Kerkvergadering wat oor 'n eie opleiding gehandel het. Later sou dit duidelike aansluiting vind by 'n teologiese rigting wat in die negentigerjare reeds goed in Nederland gevestig was, naamlik die etiese rigting. In hierdie stadium is daar myns insiens egter nog nie van 'n bewuste identifikasie hiermee sprake nie. Ons kan hoogstens sê dat die on-gereformeerdheid van Goddefroy en die ander 
Hervormde predikante en die feit dat dit sedert die sewentigerjare in Nederland moontlik was om nie-modernisties sowel as nie-gereformeerd (= nie van die 'orthodoxie' nie) te wees, hier tot uiting gekom het. Vanweë die Nederlandse konneksies van die Hervormde predikante moet dit as 'n natuurlike verskynsel geld. Dit klop met die post-kerkverenigingse konteks waarin die Hervormers bewus ongereformeerd, on-Kaaps en on-Stellenbosch was.

Dus lyk dit asof ons hier te make het met 'n konjunktuur van enersyds die modaliteite wat gedurende dié tyd in Nederland bestaan het, en andersyds die kerkpolitieke situasie in Transvaal sedert die kerkvereniging. Om redes van 'n plaaslike aard wou Henormers hul andersheid teenoor die gereformeerde teologie van die Kaapse Kerk sowel as teenoor die modemisme handhaaf, en dit is teologies moontlik gemaak deur die bestaan van 'n breë stroming in Nederland wat ook tussen 'orthodoxie' en modernisme gestaan het. Hierdie gesindheid bied 'n verklaring vir sowel die Nederlander Goddefroy se optrede in 1890 as vir die voortbestaan van sy twee pole in die Hervormde siening van die teologiese opleiding. Dit sal in die verdere verloop van die geskiedenis gesien kan word. As dit reg is, dan het die kerkvereniging ook in teologiese opsig die teenoorgestelde bereik van wat hy wou omdat die ontwikkeling van 'n tipies Hervormde teologie daardeur bevorder is. Dié teologie het al meer weg van die Nederduitsch Gereformeerde oftewel 'of'-teologie ontwikkel en 'n spiritualiteit meegebring wat al meer verskil het van dié in die kompleks Kaapse Kerk/Nederduitsch Hervormde of Gereformeerde Kerk. In hierdie opsig kan ons ook let op die teenkanting by Hervormers teen die bevindelikheid wat in die kringe van die Kaapse Kerk verteenwoordig was (vbe by Engelbrecht 1953: 313). Dit is nie alleen met die gereformeerdheid van die Kaapse Kerk in verband gebring nie, maar ook met die invloed van Skotse predikante en dus met die verengelsingsgevaar (Engelbrecht 1953: 310). Die handhawing van die Hervormde Kerk teenoor die 'Metodistiese' aspek van die verengelsingsgevaar uit die Kaap het ook diep in die bewussyn van Hervormers gebly (vgl die opstel van JJ Prinsloo 1911: 73-75, waarin dit duidelik na vore kom).

Die optrede van ds Goddefroy en die besluit van die vergadering maak goeie sin in die lig van die daaraan voorafgaande geskiedenis van die kerkvereniging waarin politieke momente 'n duidelike rol gespeel het. Ds HS Bosman, wat op Stellenbosch opgelei is, was as predikant van Pretoria ten gunste van die anneksasie van Transvaal deur Brittanje en het op 19 Mei 1877 deel gehad aan die inswering van Sir Theophilus Shepstone in, van alle plekke, die Hervormde kerkgebou van Pretoria (De Volksstem, $23 \mathrm{Mei}$ 1877). Hy, as Stellenbosser en voorstander van die kerkvereniging, is hiervoor kwalik geneem, onder andere deur ouderling ADW Wolmarans, lid van die Volksraad, kampvegter vir Hervormde belange gedurende 
die tyd van die vereniging en die Prokurasiekommissie, en vooraanstaande deelnemer aan die pogings om 'n Hervormde opleiding tot stand te bring (vgl sy Kerkhistorische Feiten, 45-48). Juis die Konsulentsgemeente van Pretoria het die burgers voorsien wat kol Anstruther op 20 Desember 1880 by Bronkhorstspruit verslaan het terwyl ds Bosman se Engelse simpatieë hom ongewild gemaak het. Die 'Stellenbossche predikanten' is al meer deur Hervormers gewantrou (Engelbrecht 1953: 302). Dit blyk duidelik uit die beskrywingspunt van die Konsulentsgemeente van Pretoria by die Algemene Kerkvergadering van 1881 dat elke predikant van die Hervormde Kerk verplicht zal zijn vóor zijne voorstelling aan de Gemeente, bij de regeering den eed van getrouwheid af te leggen aan het Gouvernement der ZuidAfrikaansche Republiek'. Tydens die bespreking het die konsulent, ds GW Smits, die beskrywingspunt gemotiveer met die opmerking dat 'de ondervinding heeft geleerd, dat er ontrouwe Predikanten zijn' (Notule Algemene Kerkvergadering 1881: 7-8). Hier het ons 'n onmiskenbare politieke motief vir die afkeer by Hervormers aan Stellenbosch.

Dit word verder bevestig deur die politieke element in die optrede van ouderlinge MJ Prinsloo en CJ Joubert, die leiersfigure onder die Hervormers wat nie wou verenig nie. Om 'n predikant te bekom, het hulle hul tot Nederland eerder as tot Stellenbosch gewend. Die Hervormers was bewus van die 'ou Hollandse gees' (soos Engelbrecht 1953: 310 dit noem) wat in teenstelling gestaan het tot wat hulle beleef het as die Engelse invloed in die Kaapse Kerk en die oordrag daarvan op die verenigde gemeentes. Hierdie afwysing van verengelsing op kerklike gebied het hand aan hand gegaan met 'n gesteldheid op die politieke onafhanklikheid van die ZAR, soos blyk uit die beskrywingspunt waarop hierbo gewys is. Die Volksraad van die ZAR het dit ook waardeer, getuige die besluit van 26 Mei 1886 (no 322; ook aangehaal in die Notule van die Algemene Kerkvergadering van 1893, bl 36), waarin versigtig waarderende woorde uitgespreek is teenoor albei kante in die dispuut oor wie nou die staatskerk was. Ook die rassekwessie het 'n rol gespeel, onder andere in Zoutpansberg waar die Hervormers nie 'saam met die kleurlinge en Kaffers dieselfde predikant' wou he nie (Engelbrecht 1953: 313). Die teenkanting teen Stellenbosse predikante en die keersy daarvan, die hoop op hulp van Nederlandse predikante, moet dus ook in die lig van die politieke onafhanklikheidstrewe van die Hervormers in die ZAR gesien word omdat dié strewe in die woelinge van die kerkvereniging ' $n$ rol gespeel het.

Die koppeling van politieke motiewe aan die 'kerkkwestie' en dus ook aan die teologiese oriëntering van die predikante en die opleiding, kan goed waargeneem word in die wyse waarop ds Goddefroy beroep is en in die gebeure kort ná sy aankoms in Transvaal. In die eerste plek was een van die leiers van die Hervormers, 
ouderling CJ Joubert, ook vise-president van die ZAR en as sodanig heftig gekant teen die verengelsingsgevaar uit die Kaap. Dit het die onafhanklikheid van die ZAR sowel op politieke gebied (1877 ev) as op kerklik-kulturele gebied (1885 ev) bedreig. Hierdie bewussyn word deur vise-president Joubert uitgespel in 'n brief aan jonkheer Beelaerts van Blokland, gesant van die ZAR in Europa en die bemiddelaar van die Hervormers in hul poging om 'n Nederlandse in plaas van 'n Stellenbosse predikant te kry. Op 5 Januarie 1887 skryf hy die volgende betekenisvolle woorde aan die gesant (teks by Engelbrecht 1953: 315):

Dat ik bij $\mathrm{U} E$ aandring is niet alleen voor Kerk maar ook voor Staat, want hoe meer de godsdienst hier kan versterkt worden door predikanten uit Holland, hoe meer onze vrijheid gewaarborgd is. $U$ kunt zelf begrijpen, welken invloed het op de bevolking kan uitoefenen, indien de meerderheid van de predikanten alhier van gevoelens Engelsch zijn, en daarom is het voor ons van zoo'n groot belang. Onze oude Kerk moet in stand gehouden worden, wil men onze vrijheid duurzaam doen blijven.

Dan gaan hy voort om te vra dat die gesant moet soek na 'n predikant wie se 'trouw aan de Hervormde Kerk' vasstaan en om te betoog dat Holland sy doel 'om Transvaal goed te doen' alleen sal bereik deur predikante te stuur, 'want door den omgang met Hollandsche leeraren worden de twee elementen tot een gebracht, en dit is een kracht voor ons land'. Die 'twee elementen' is die politieke onafhanklikheid ('vrijheid') en kerklike onafhanklikheid ('godsdienst'). Laasgenoemde is nodig om eersgenoemde te behou ('waarborgen') en word, in die vise-president se eie woorde, 'tot een gebracht'. Dit word alreeds gesuggereer deur die feit dat die vise-president vir 'n kerklike doel gebruik maak van die staat se gesant. Nog 'n sprekende verskynsel in die brief, en myns insiens van groot betekenis, is die eenvoudige aanvaarding dat 'de Hervormde Kerk' in Nederland dieselfde is as dié in die ZAR - as die te beroepe predikant aan die Nederlandse Hervormde Kerk trou is, dan is hy ook aan die Transvaalse Hervormde Kerk trou. In hierdie brief het ons die locus classicus waardeur die hele teneur van die gevoelens rondom die kerkvereniging, kerklike identiteit en die politieke ondertone daarvan bevestig word.

Dit word onderstreep deur verskeie briewe aan Beelaerts van Blokland deur die onderwyser, W Louis, wat as sekretaris vir die Hervormers opgetree het (teks by Engelbrecht 1953: 316): 
De oude hervormde partij is heelemaal voortrekkers element en Krugers gezind (anti-Kaapsch, anti-Engelsch), redenen waarom president Kruger ook zoo gaarne de Hervormde Kerk weer op de been zag. Kruger steunt $C \mathrm{~J}$ Joubert sterk en deze twee partijen samen kunnen nog $3 / 4$ van het land uitmaken (5 Januarie 1887.)

Mocht toch de a s predikant van de Hervormde Kerk maar een man zijn die bij een vroom gemoed, alle lust heeft om te staan tegenover de Kaapsche partij, wier ernstig streven is om ons zoo spoedig mogelijk geestelijk Engelsch te maken (21 Januarie 1887).

Ds Goddefroy, predikant te Achlum, Friesland, het aan hierdie verwagtinge voldoen en is beroep. Op 16 Junie 1887 het hy in sy skriftelike antwoord op die welkomsadres blyke gegee van die teologiese oriëntering waarop ek in die bespreking van die Algemene Kerkvergadering van 1890 gewys het: 'Geen Kerk zonder belijdenis; maar ook geen belijdenisschrift of formulier boven of nevens het onbedriegelijke Woord des Heeren'. Die eerste element in hierdie uitspraak is 'n afgrensing teenoor die vrysinnige modernisme, en die tweede 'n afgrensing teenoor die 'orthodoxie', soos die gereformeerde gesindte in die kontemporêre teologiese debatte geheet het. Dit reflekteer 'n teologiese oriëntering wat klop met sy agtergrond as student in Utrecht. Hier het hy onder die sogenaamde vroeëre etiese teoloë', JJ van Oosterzee (die promotor van Valeton jr), JI Doedes en N Beets gestudeer. Dit klop ook met sy afwysing van die modernisme en van die gereformeerde beweging van Kuyper (vgl Botha 1977: 23). Beide dié pole is ook geïdentifiseer deur sy biograaf, SJ Botha (1987: 59), hoewel in ietwat ander terme beskryf. Geen wonder nie dat hy vir hierdie teologiese oriëntering onder skoot gekom het. In De Zuid-Afrikaan van 16 April 1887 het ds FL Cachet hom daarvoor gekritiseer en ds HS Bosman het sewe bydraes oor 'De Leerkwestie' in De Volksstem van Januarie en Februarie 1887 geskryf waarin ds Goddefroy van modernisme beskuldig is. Dit is dieselfde as wat met nie-gereformeerde en tegelykertyd nie-modernistiese teoloë in Nederland van daardie tyd gebeur het. Gereformeerdes (die 'orthodoxie') het hierdie teoloë doodgewoon as modernisties beskou en soms selfs as nog erger (vgl Loader 1984: 169; Lindeboom 1916: 856). Goddefroy se antwoord in die brosjure van 1890, De kerkkwestie: Niet een leer-maar een levenskwestie, het sy posisie nogeens verduidelik. Aan die een kant het hy die vrysinnigheid van die modernisme afgewys en aan die ander kant die ortodoksie se de facto onderwerping van die Bybel aan die belydenisskrifte gekritiseer. Tegelyk het hy ook gese waarom al die twis gedraai het - die lewenskwessie van verengelsing, dus die bedreiging van die 
kerklik-kulturele aspek van die Transvaalse onafhanklikheid.

Hierdie hele geskiedenis toon dat Goddefroy se siening oor 'n eie teologiese opleiding, uitgespreek in dieselfde jaar as die verskyning van De Kerkkwestie, in lyn is met sy teologiese herkoms en met die kerkpolitieke ontwikkelinge in die ZAR.

\section{Die Algemene Kerkvergaderings van 1893, 1897 en 1899.}

Ouderling $\mathrm{CJ}$ Joubert het by die eerste geleentheid die saak van die opleiding weer te berde gebring. Tydens die Algemene Kerkvergadering van 1893 het hy 'n beskrywingspunt ingedien waarin die Kerk gevra is om die opleiding van 'onze landszonen' as predikante te reël (Notule, bl 53). Ds Goddefroy se standpunt van drie jaar tevore, dat Hervormde predikante 'n breë kulturele opleiding aan 'n universiteit moes kry, het weer na vore gekom (Notule, bl 53). Die besluit wat geneem is, was egter vaag. Die Algemene Kommissie het opdrag gekry om weẻ te ondersoek 'om onze eigen landszonen in dit land te doen opleiden tot Predikanten onzer Kerk' (Notule, bl 54). Dit kon beteken dat 'n eie opleiding aan 'n kweekskool tot stand moet kom of dat die studie van 'landszonen' aan 'n universiteit moontlik gemaak moes word. Die nagevolge van die kerkvereniging, die aktiwiteite van die Prokurasiekommissie wat op pad terug na die Hervormde Kerk was, en die onrus op kerklike gebied was egter nog voluit aan die gang en daar het niks van gekom nie.

Op die Algemene Kerkvergadering van 1897 het die belangstelling van ouderling ADW Wolmarans, wat intussen aan die voorpunt van die Prokurasiekommissie uit die verenigde kerk getree en weer in die Hervormde Kerk opgeneem is, op die voorgrond gekom. Hy sou oor die volgende jare 'n prominente aandeel in die totstandkoming van 'n eie teologiese opleiding hê. Hy het die leiding geneem by 'n beskrywingspunt van die gemeente Pretoria waarin gevra is dat die Kerk moet ondersoek hoe daar reeds 'met het oog op de opleiding van hare aanstaande Evangeliedienaren' gebruik gemaak kan word van die eerste sekondêre skool in die ZAR, die Staatsgymnasium wat in 1893 tot stand gekom het (Notule, bl 11). Dit kon beteken dat ondersoek na die fasiliteite van die Gymnasium gedoen moet word en sou dan suggereer dat aan 'n kweekskool gedink is (wat wel twee jaar later Wolmarans se bedoeling was). Dit is egter ook moontlik dat die bedoeling was dat voornemende predikante reeds aan die Gymnasium voorberei moes word vir die universitêre studie. Hiervoor pleit dat ds Goddefroy se sterk aandrang op universiteitsopleiding vir predikante groot gewig gedra het, sowel as die feit dat die Volksraad die vorige jaat reeds opdrag tot 'n wetsontwerp op die oprigting van 'n universiteit in Pretoria gegee het en dat Goddefroy dit op die vergadering vermeld het (Notule, bl 13). Die voorstel is met steun van sowel die voorsitter, ds Goddefroy, as die skriba, 
ds Van Belkum, aanvaar.

Ook tydens die Algemene Kerkvergadering van 1899 het Wolmarans die saak van 'n Hervormde opleiding bepleit. Die kerkraad van Rustenburg het 'n beskrywingspunt ingedien waarin uitdruklik gevra is vir 'eene school tot opleiding van predikanten voor de Ned Herv Kerk in de Zuid-Afrikaanse Republiek', dus vir 'n kweekskool (Notule, bl 13). Wolmarans se amendement op die voorstel, wat met algemene stemme aangeneem is, het gelui dat aan alle kerkrade opgedra word om met die gemeentes oor die oprigting van 'een school voor de opleiding van predikanten in de Zuid-Afrikaansche Republiek' te onderhandel, en om hulle in te lig dat so ' $n$ inrigting tot stand kan kom as elke lidmaat 5 sjielings per jaar bydra (Notule, bl 14). Dit was dus nog slegs 'n kwessie van onderhandeling met die gemeentes, maar in beginsel het niemand op die vergadering beswaar gehad teen die oprigting van 'n kweekskool nie. Die rede hiervoor moet waarskynlik in die verdonkerende politieke situasie gesoek word. Die konfrontasie tussen die ZAR en Brittanje het toegeneem en die Driejarige Oorlog sou 'n paar maande later uitbreek. In sulke omstandighede het die desideratum van 'n universitêre opleiding nie opgeweeg teen die noodsaak van 'n eie opleiding nie. Hierdie interpretasie word ook aan die hand gedoen deur die aanhef van Wolmarans se voorstel: 'De Eerw Algemene Vergadering der Ned Herv Kerk de oprichting van een school voor de opleiding van predikanten in de Zuid-Afrikaansche Republiek als de levenskwestie der kerk beschouwende...' Dit bevat 'n aanhaling uit die titel van Goddefroy se beroemde brosjure waarin die politieke motiewe na vore tree wat tydens die kerkvereniging hul rol gespeel het. Die lewe van die kerk en die lewe van die republiek word bedreig, en daarom is 'n eie opleiding nodig. Hierdeur word die verband wat ek hierbo tussen die politieke en kerklike agtergronde van die eerste stemme vir 'n opleiding gelê het, bevestig. Dit was nog al die tyd dieselfde, behalwe dat die bedreiging intenser en die noodsaak vir 'n eie opleiding groter geword het. Dit is waarskynlik waarom ds Goddefroy, ten spyte van sy teenkanting teen 'n kweekskool, nie die oprigting daarvan teengestaan het nie. Die prys was nou te hoog. Ná die oorlog, in 1909, sou hy weer sy ou teenstand teen 'n kweekskool hervat en dit uitdruklik in verband bring met sy ervaring van die oorlog. Op hierdie vergadering was alle sprekers, insluitende die skriba, ds Van Belkum, egter ten gunste van 'n kweekskool. Die verband met die bittere ervaring van die kerkvereniging, die onaanvaarbaarheid van Stellenbosch, en die verlange na die 'oude paden' (dit wil sê van die Voortrekkers) is ook duidelik op die vergadering uitgespreek (Notule, bl 3). Telkens kom dieselfde motiewe na vore, en so sou dit ook nog vir jare bly. 
Dit is interessant dat Wolmarans presies twee maande ná sy kweekskoolvoorstel, op 10 Maart 1899, in die Volksraad gepleit het vir die oprigting van 'n universiteit in Pretoria en dat die Volksraad inderdaad daartoe besluit het (Notule, Art 274a). Die feit dat daar dadelik begin is met die soektog na Nederlandse professore in die regte en teologie toon dat Wolmarans nie die Hervormde desideratum prysgegee het nie. Daarom moet ons sy kweekskool-voorstel van 10 Januarie na alle waarskynlikheid wel beskou soos dit hierbo geinterpreteer is - as 'n noodmaatreël om ten alle koste Engelse invloed te beperk - terwyl hy daarna nog probeer het om die ander aspek, die breë kulturele ideaal van Goddefroy, daarmee te kombineer. Op grond hiervan (en op grond van Goddefroy se latere heropname van sy teenkanting teen 'n kweekskool) kan gesê word dat die Hervormde Kerk selfs nie by sy (voorlopige) kweekskool-besluit van 1899 die ideaal van 'n algemene kulturele vorming van sy studente aan 'n universiteit prysgegee het nie. Daar het egter weer niks van gekom nie, want in Oktober van dieselfde jaar het die verwoesting van die Driejarige Oorlog losgebreek.

\section{DIE ANDERHALWE DEKADE Ná DIE DRIEJARIGE OORLOG}

\subsection{Die eerste 'landszoon'}

As gevolg van die verwoesting van die oorlog het die eerste Algemene Kerkvergadering ná die vredesluiting, dié van 1903, nie veel aandag aan die opleidingskwessie geskenk nie. Dit het wel ter sprake gekom, maar al wat die vergadering besluit het, was om die Transvaler P van Drimmelen te ondersteun in die teologiese studie waarmee hy in 1902 aan die Rijksuniversiteit te Utrecht begin het.

\subsection{Die eerste plaaslike opleiding}

Tussen 1906 en 1909 het die eerste 'eie teologiese opleiding' van die Hervormde Kerk in Pretoria plaasgevind. Die interessante hiervan is dat dit sonder die daarstelling van formele strukture gebeur het en in 'n sekere sin die ideaal van 'n eie opleiding gekombineer het met die vertroue in Nederlandse leermeesters. In 1904 het prof PJ Muller saam met ds LE Brandt uit Nederland gekom om respektiewelik die Hervormde gemeentes Pretoria en Zoutpansberg te bedien. Laasgenoemde was 'n leerling van Valeton in Utrecht en is vanweë intieme huislike bande lewenslank sterk beïnvloed deur die etiese teoloog par excellence, JH Gunning jr. Sy belang by die opleiding spreek uit sy deelname aan die vroeë debatte oor 'n kweekskool en latere deelname aan die aktiwiteite van die kuratorium. Muller was van 1890-1896 
kerklike professor aan die Gemeentelijke Universiteit te Amsterdam waar sy opdrag die opleiding van predikante vanweë die Hervormde Kerk was. Vanaf 1894 het die gereformeerde groepe onder Abraham Kuyper teenkanting teen die Hervormde opleiding in Amsterdam begin bied, waarna dit tot 'n einde gekom het. Vanaf 1896 was Muller predikant in die gemeente Haarlem. Hy het in Groningen onder J Cramer en GH Lamers gestudeer en in Junie 1881 oor die godsleer van Calvyn gepromoveer. Muller was 'n voortreflike geleerde wat nie net as sistematikus nie, maar ook as Hebraikus en kenner van die Joodse literatuur uitgemunt het (vgl sy De Godsleer der Middeleeuwsche Joden wat in 1898 verskyn het en verbande tussen Joodse filosowe en die Katolieke skolastiek gelê het). As sodanig was hy uitnemend geskik vir die taak wat hy naas sy gemeentelike bediening in Pretoria kom aanpak het. Hy het naamlik twee jaar ná sy aankoms begin om twee jong 'landszonen' as predikante op te lei. Dit is moontlik geïnisieer deur die feit dat die skriba van die Algemene Kerkvergadering, ds $\mathrm{J}$ van Belkum, die saak in 'n brief van 4 April 1905 aan die invloedryke ouderling ADW Wolmarans te berde gebring het (vgl Engelbrecht 1953: 368).

Die latere predikante JJ Prinsloo en JJ Kuhn is drie jaar lank deur hom opgelei. Hoewel die inhoud van hierdie kursus vanweë die informele aard daarvan moeilik beoordeel kan word, moet ons aanvaar dat Muller sy eie teologiese oriëntering aan hulle oorgedra het. Dit beteken dat die eerste twee plaaslik opgeleide predikante die invloed van die tipiese 'derde opsie' van die destydse Nederlandse toneel ondergaan het, dit wil sê 'n nie-gereformeerde mar ook niemodernistiese vorming ontvang het. Die Kerk het die opleiding amptelik gesteun deurdat die Algemene Kommissie dit goedgekeur en finansieel help dra het (hoewel die fondse wat vir die toelae van prof Muller uit die gemeentes gevra is, nie aan die verwagtinge voldoen het nie). Die opleiding was dus informeel vir sover daar geen struktuur daarvoor geskep was nie, maar amptelik omdat dit die goedkeuring van die Kerk gehad het. Die twee studente het dan ook ná die Algemene Kerkvergadering van 1909 by die Algemene Kommissie eksamen afgelê en is in die Kerk beroepbaar gestel. Reeds in hierdie stadium is dit moontlik om die teologiese atmosfeer te tipeer waarin die gesprekke oor en eerste inisiatiewe in die Hervormde teologiese opleiding plaasgevind het. Dit is kennelik dié waaruit Nederlanders gekom het soos Muller, Brandt, Van Belkum (ook 'n doktorandus van Utrecht) en Afrikaners soos HCM Fourie (hy het te Utrecht in die godsdiensgeskiedenis gepromoveer maar ook onder Valeton in die Ou Testament gestudeer en later vertaler van die Ou Testament geword). 


\section{Die Algemene Kerkvergadering van 1909}

In 1909, die jaar waarin hy, ná verstryking van sy ooreengekome periode van vyf jaar, na Nederland terug is, was Muller nog voorsitter van die Algemene Kerkvergadering. Op die vergadering van die jaar het 'n rapport van die Algemene Kommissie oor die oprigting van 'n kweekskool gedien waardeur die klanke ten gunste van so 'n inrigting weer opgeroep is. Blykens die notule het ouderling ADW Wolmarans weer 'n leidende rol by die bepleiting daarvan gespeel.

Uit sy bydrae kom veral twee aspekte na vore: Enersyds motiveer hy die noodsaak van 'n eie opleiding weer soos by die Algemene Kerkvergadering van 1899 met 'n politieke argument. 'Onze Kerk is een sterke factor voor onze nationaliteit, moet het zijn ook voor de toekomst.' Die onafhanklikheid van die ZAR is verloor, maar daar les 'n stryd voor om die onafhanklikheid van die Afrikaner te verseker. Hierin lê 'n duidelike strewe na kultureel-godsdienstige onafhanklikheid, maar die gebruik van die term 'nationaliteit' suggereer ook 'n politieke strewe - wat vanselfsprekend is in die lig van die feit dat, soos ons hierbo gesien het, die Hervormers reeds vir meer as twee dekades bang was vir die verlies van hul 'vrijheid' via 'n geestelike verengelsing deur Kaapse predikante. As die Hervormde Kerk in die jare ná die kerkvereniging hiervoor bevrees was, dan het dieselfde vrees a fortiori nou gegeld. En as 'n kweekskool voor die oorlog nodig was om politieke onafhanklikheid deur kerklike onafhanklikheid te rugsteun, dan was 'n kweekskool ná die oorlog des te nodiger om die effek van die verlies van eersgenoemde deur die handhawing van laasgenoemde teen te werk. Daarom is dit heeltemal in lyn met Wolmarans se optrede in 1899 wanneer hy in 1909 die pad vorentoe soos volg voorsien: 'Wij zullen moeten strijden en daarvoor hebben wij onze eigene mannen nodig', en wanneer hy sy pleidooi vir onafhanklikheid begrond met die retoriese vraag: 'Is het niet tijd ons voor te bereiden voor den strijd die komen zal?' Die konklusie is eenduidig: Die Afrikaner se stryd moet gestry word deur die kerk; daarom is 'onze eigen mannen nodig'; daarom is 'n eie opleiding nodig. Soos ons by die bespreking van die vooroorlogse periode gesien het, was politieke en daarom kerkpolitieke oorwegings die vernaamste dryfveer in die strewe na 'n eie opleiding. Sake soos teologiese oriëntering en die desiderata wat daarmee saamhang, moes tweede viool speel en is in 'n groot mate bepaal deur die politieke oorwegings. Daarom dat die voorkeur van 'n universiteit bo 'n kweekskool nie in 1899 belangrik was nie, al moet bygevoeg word dat, hoewel die klasse by die destydse TUK in 1908 'n aanvang geneem het, daar in 1909 nog nie 'n vooruitsig op ' $n$ volwaardige universiteit was nie.

Die tweede aspek van Wolmarans se toespraak op die Algemene Kerkvergadering wat vir ons doel belangrik is, is die feit dat hy die hele kwessie van die 
opleiding, die gronde daarvoor en die vooruitsigte daarvan uitdruklik in verband bring met die kerkvereniging van 1885/6. In die konteks van sy betoog dat die Hervormde Kerk nie op Stellenbosch moet reken vir die voorsiening van sy predikante nie, en van sy betoog dat die kerk die 'nationaliteit' onderskraag, verwys Wolmarans na die vereniging. 'De Vereniging gaf ons bittere hoon en strijd. Onze predikanten zijn gehoond en gesmaad.' Dit is duidelik dat daar volgens Wolmarans geen hoop is dat die stryd van die toekoms suksesvol gestry sal kan word as daar gesteun moet word op predikante uit Stellenbosch wat verantwoordelik was vir die interne stryd van die vooroorlogse jare nie. Hierdie aspek toon dat dit korrek was dat ons die overture tot 'n eie opleiding gedurende die vooroorlogse jare in die lig van die kerkvereniging gelees het. Dit bevestig ook die juistheid van die logika Afrikanerstryd - 'eigen mannen' - eie opleiding, waarheen die vooroorlogse ontwikkelinge sowel as die besprekings van die 1909-Algemene Kerkvergadering wys.

Die oprigting van ' $\mathrm{n}$ eie kweekskool is deur verskeie ouderlinge gesteun, sowel as deur onder andere di J Van Belkum, LE Brandt, CJL Ruysch van Dugteren, KT van den Heever, PW Ennis, en die 'landszoon' ds P van Drimmelen, wat in Utrecht gestudeer het.

Teenstand het egter nie uitgebly nie. Hiervoor is veral geldelike gronde aangevoer, maar ds Goddefroy het ook 'n teologiese oorweging genoem. Waar hy in 1899 akkoord gegaan het met die oprigting van 'n kweekskool, het hy nou gevoel dat kerklike eenheid nie deur die stigting van so 'n skool gedien sou word nie en dit daarom teengestaan. Goddefroy het die ervaring van die Driejarige Oorlog as die oorsaak van sy nuwe insig genoem. Dit impliseer dat die politieke nederlaag van die Afrikaner by Goddefroy 'n kerklike impak gehad het en dat die lotsgebondenheid van kerk en volk dus ook by hom 'n rol gespeel het, al het dit op 'n ander manier tot uiting gekom as in die begeerte na 'n eie opleiding. Dit is egter ook nodig om daarop te let dat hy reeds in 1890 die oprigting van 'n kweekskool sterk teengestaan het vanweë sy oortuiging dat die Kerk 'n universitêre opleiding nodig het en dat daar dus ook ander redes was waarom hy 'n eie kweekskool sou teenstaan.

Die voorstanders het egter die oorhand gehad en die vergadering het besluit om 'n Hervormde kweekskool op te rig. Hiermee saam is besluit dat elke gemeente sou bydra tot die onkoste daarvan sowel as dat 'n kuratorium aangewys sou word. Die konsepreglement vir die kweekskool en vir die eksaminering van teologiese kandidate sowel as van godsdiensonderwysers is na die kerkrade vir oorweging verwys.

Die gedagtes wat by hierdie Algemene Kerkvergadering uitgespreek is, het ook in die volgende jare na vore getree in die twee publikasies van die Kerk, die Almanak en Die Henvormer. Ds JJ Prinsloo (1911: 73-75) het byvoorbeeld uitvoerig 
betoog dat die Hervormde Kerk 'die oude voortrekkergeest' bewaar, dat 'n kweekskool nodig is juis om die eie karakter van die Voortrekkers te behou en dat Skotte ('bovendien wekt die naam onaangename herinneringen op') nie goed genoeg vir ons is nie. In hierdie verband bring hy ook die kerkvereniging ter sprake en oefen sydelings kritiek uit op diegene wat die Hervormde Kerk se regsinnigheid bevraagteken. Dit is alles tipies van wat ons in die bestudering van die vooroorlogse aanloop gevind het, en nie toevallig deel van 'n artikel getiteld 'Onze Kweekschool' nie (my beklemtoning). Byna elke nommer van Die Hervormer het in hierdie jare korrespondensie oor 'n eie opleiding bevat. Die twee vooropstaande oorwegings was die finansiële aspekte daarvan (vgl ter illustrasie Die Henormer, 14 Februarie 1912, bl 10) en die onaanvaarbaarheid van Stellenbosch (vgl ter illustrasie Die Hervormer, 15 Desember 1911, bl 10).

Volgens die konsep sou die toelatingsvereistes matriek plus 'n kennis van Hebreeus en Grieks wees. 'n Driejarige kursus sou aangebied word in die volgende vakke: Uitleg van die Ou Testament, Uitleg van die Nuwe Testament, Leerstellige Godgeleerdheid, Kerkgeskiedenis en Wysbegeerte van die Godsdiens. Tweejarige kursusse sou aangebied word vir: Bybelse Godgeleerdheid, Bybelse Geskiedenis en Godsdiensgeskiedenis. Eenjarige kursusse sou wees: Christelike Sedekunde en Praktiese Godgeleerdheid. Hierdie leergang is kennelik gebaseer op die vakgebiede wat sedert 1877 met die invoering van die 'Wet op het Hooger Onderwijs' in Nederland aan teologiese fakulteite gedoseer is. Hoewel ons nie te ver kan gaan met ' $n$ interpretasie van so 'n raamwerk nie, is die onderskeid tussen 'leerstellige' en 'Bybelse' godgeleerdheid van belang. Dit verteenwoordig 'n perspektief op die teologie wat vreemd was aan die 'orthodoxie' van dié periode. Waar die 'orthodoxie' die Bybel as 'n leerstellige referensiebron gehanteer het en dus geen plek vir 'n Bybelse in onderskeiding van 'n dogmatiese teologie gehad het nie, was hierdie onderskeiding weer kenmerkend van die 'derde opsie' tussen gereformeerde ortodoksie en modernisme in Nederland. Dit is dus geregverdig om te konkludeer dat die voorgenome leergang sterk beïnloed is deur die 'derde opsie' in Nederland. Hiervoor spreek ook die feit dat die Hervormde predikante wat vir die opstel daarvan verantwoordelik was, juis deur professore van hierdie modaliteit gevorm is. Te Utrecht en Groningen, waar die meeste van hulle gestudeer het, was dit in die laaste kwart van die negentiende en die eerste jare van die twintigste eeu juis professore wat uitgemunt het in die 'Bybelse' en 'historiese' teologie en in die begronding van die onderskeid tussen hierdie teologie en die dogmatiek wat die kalklig gesteel het met hulle opposisie teen die gereformeerde sowel as die liberale teologie. Onder hulle het veral JJP Valeton jr in Utrecht, JJP Valeton sr en G Wil- 
deboer in Groningen, laasgenoemde later ook in Leiden, en JH Gunning J Hzn, vroeër van Utrecht en later dosent in Amsterdam, getel.

\subsection{Die eerste Kuratorium}

Die Kuratorium het vir die eerste keer op 19 Julie 1909 byeengekom met ds CW du Toit as voorsitter, ds $\mathbf{J}$ van Belkum as skriba en onder die lede ook ouderling ADW Wolmarans. Die jaar daarna het die Kuratorium prof PJ Muller, wat intussen na Nederland teruggekeer het, as eerste dosent benoem. Hy het bedank en die Hervormde predikant van Beesd, die latere Groninger professor WJ Aalders aanbeveel.

Ook in 1910 het die Unie-Parlement wetgewing aangeneem waardeur die Transvaalse Universiteitskollege as konstituerende kollege van die Universiteit van Suid-Afrika opgerig sou word. Dit het opnuut die totstandkoming van 'n teologiese fakulteit binne die gesigskring gebring. Dit word soms gesê (bv Engelbrecht 1953: 368) dat die vertraging in die totstandkoming van die te stigte kweekskool veroorsaak is deur die roeringe wat die Ruysch van Dugterensaak gehad het. Die medeleraar en opvolger van Muller in Pretoria het in Julie 1911 die letterlikheid van sy aanvaarding van die ondertekeningsformulier bevraagteken. Groot opskudding is veroorsaak deur sy opvatting oor die uitverkiesingsleer en leervryheid. Hy is ten slotte finaal deur die Algemene Kerkvergadering van 1912 afgesit, waardeur weer eens aangetoon is dat die Hervormde Kerk nie leervryheid wou duld nie. Dieselfde Algemene Kerkvergadering het ook besluit dat daar met die regering onderhandel moes word met die oog op die totstandkoming van 'n universitêre opleiding van predikante. Dit kan derhalwe nie ingesien word hoe die oprigting van 'n kweekskool bespoedig sou word as die Ruysch van Dugterensaak nooit plaasgevind het nie. Hierdie Algemene Kerkvergadering moes in elk geval die totstandkoming van die kweekskool waarop die 1909-Algemene Kerkvergadering besluit het, finaliseer omdat daar nog allerlei vir oorweging na die gemeentes verwys is. Dit kon alleen in 1912 gebeur, en intussen, die jaar ná die vorige vergadering, het die vooruitsig op 'n universiteit nie net 'n moontlikheid nie, maar 'n werklikheid geword.

Die feit dat die Kuratorium nog in 1912, voor die Algemene Kerkvergadering van daardie jaar, twee predikante genader het met die oog op opleiding van voornemende predikante, beteken nie dat hulle formele benoemings gemaak het (soos Engelbrecht 1953: 368-369 beweer) nie. Twee doktorandi uit die dampkring van Valeton in Utrecht, di J van Belkum en HCM Fourie, is deur die Kuratorium gevra 'of zij genegen zijn voorlopig de opleiding van jonge mannen...op zich te 
nemen' (my beklemtoning). Die bewoording dui allermins op 'n benoeming en kan hoogstens as voelers in die rigting van moontlike kandidate vir dosentskappe opgeneem word. Dieselfde voorlopigheid spreek uit die feit dat die Kuratorium die saak vir die Algemene Kerkvergadering, wat op hande was, gelaat het toe ds Fourie negatief op die navraag gereageer het.

Die Kuratorium het in hierdie tyd ook nog 'n ander funksie verrig. Twee 'landszonen' was reeds in Nederland besig met studie in die teologie, $S$ Vermooten in Utrecht en SJ Strydom in Leiden, en die Kuratorium het hulle ondersteun. Dus het dit binne sy werksterrein geval om die ou alternatief vir Stellenbosse studie, naamlik universiteitsopleiding in Nederland, te bevorder. Hiermee het die Kuratorium voortgegaan tot in 1916, die jaar voordat die teologiese opleiding aan die Transvaalse Universiteitskollege gefinaliseer is.

\subsection{Die finale stappe tot die teologiese opleiding}

Die Algemene Kerkvergadering het in Mei 1916 besluit om dit aan sy kuratorium op te dra om namens die Hervormde Kerk 'n professor in teologie te benoem as die universiteit in Pretoria tot stand kom. Die maand daarna het die TUK die Kerk genader om hulp te verleen by die oprigting van 'n teologiese fakulteit aan die komende universiteit. Die Kuratorium het hieroor gehandel by sy vergadering van Julie 1916, en by sy vergadering van 25 Januarie 1917 besluit om 'deel te nemen aan de oprichting van een Theol fakulteit aan genoemde Univ.' Daar is uitdruklike voorwaardes aan die Raad van die TUK gestel: dat ten minste een van die teologiese professore 'Hollandssprekend' moes wees, dat by die aanstelling van professore 'rekening wordt gehouden met de beginselen der Ned Herv Kerk in ZA', dat die kerklike professor in rang gelyk aan universiteitsprofessore sou wees, dat die 'verdeling der vakken' in oorleg met die kerklike professor sal geskied, en dat die Hervormde teologiese studente as universiteitstudente sal geld. Dit is aanvaar en die Hervormde teologiese opleiding was 'n werklikheid.

Op dieselfde Kuratoriumvergadering is dr JHJA Greyvenstein as die eerste Hervormde professor benoem. Dit het geskied ná menige meningsverskil tussen die ou Afrikaner-strydros, ADW Wolmarans, wat liewer 'n Nederlander wou hê sodat dr Greyvensteyn sy goeie werk in die gemeente Pretoria kon voortsit, en die Nederlander Jac van Belkum wat prinsipieel 'een geboren Afrikaner' wou hè. Die benoeming van Greyvenstein het die tradisie van die strewe na 'n eie Hervormde opleiding voortgesit. Hy was 'n Kaapse rebel, wie se simpatie met die Afrikanersaak dus bo twyfel was, en, hoewel hy aan Stellenbosch gestudeer het, het hy in Utrecht gepromoveer in dieselfde teologiese atmosfeer as dié waaruit Goddefroy, Van 
Belkum, Fourie en ander predikante onder die ou bedeling (soos Van Drimmelen) gekom het. Sy proefskrif, Het sociale urilisme van Bentham, verteenwoordig die beginpunt van sy lewenslange belangstelling in die etiek. Hy het juis groot waardering gehad vir die prominente leiersfiguur onder die etiese teoloë, Valeton jr, wat onder sy leermeesters getel het. Die 'verengelsingsgevaar' was egter nie buite gesigsveld nie, want rev E MacMillan is vanweë die Presbiteriaanse Kerk as kerklike professor aangestel en het saam met Greyvenstein die rang van universiteitslektor gehad. Vir Hebreeus is prof AC Paterson aangestel. Op 1 April 1918 het die driemanskap as Fakulteit Teologie van die TUK begin.

Die Hervormde Kerk was die enigste wat van die fasiliteite gebruik wou maak. Hoewel daar in 1917 slegs twee studente ingeskryf het, naamlik PJJ Venter en MMJ Basson, en hoewel laasgenoemde nie die studie voltooi het nie, het die Hervormde Kerk deur sy amptelike betrokkenheid en steun die belangrikste krag aan die fakulteit geword. So het dit 'n Hervormde fakulteit geword.

\section{LATERE AANSTELIINGS}

In 1921, drie jaar nadat die fakulteit begin het met sy werksaamhede, is dr SP Engelbrecht as lektor in die fakulteit aangestel. Kort daarna het die TUK met die Kerk ooreengekom dat die twee kerklike dosente ook die status van universiteitsprofessor sou kry. Engelbrecht het sedert 1913 in Utrecht gestudeer, eers vir die kandidaatseksamen en daarna as doktorale student tot by sy promosie oor die geskiedenis van die Nederduitsch Hervormde Kerk van Afrika in 1920. Waar Greyvenstein die invloed van Valeton ondergaan het, was Engelbrecht een jaar te laat om hom mee te maak. Hy het egter blywend onder die invloed van Valeton se vertroueling en ewe bekende leier van die etiese beweging, HTh Obbink, gekom en jare lank goeie betrekkinge met hom onderhou. Die tipiese tweefront-stryd van die etici kan ook in Engelbrecht se lewenswerk waargeneem word, sy dit ook in sy Afrikaanse gestalte. Aan die een kant staan 'n duidelike afwysing van die modernisme of liberalisme soos dit veral in sy tyd genoem is. Dit kan duidelik gesien word in sy opus magnum, die Geskiedenis van die Nederduitsch Hervormde Kerk van Afrika, wat uit sy proefskrif gegroei en verskeie uitgawes beleef het. Juis sy beskrywing van die periode wat ons hier interesseer, illustreer hierdie punt. Sy bewoë en partisane beskrywing van die geskiedenis wemel van uitsprake oor die onaanvaarbaarheid van leervryheid, vrysinnigheid en teologiese liberalisme (bv oor die Ruysch van Dugterensaak, Engelbrecht 1953: 370-373). Aan die ander kant staan die afwysing van wat hy graag 'Neo-Calvinisme' en 'leerheiligheid' genoem het, naamlik die gereformeerde ortodoksie. Dit blyk ook uit sy beskrywing van die periode waarmee 
ons ons hier besig gehou het (bv oor Goddefroy, wie se teologiese standpunt 'heeltemal ooreengekom [het] met dié van die Hervormde Kerk in Transvaal', wat nie alleen die modernisme afgewys het nie, maar ook die gereformeerde ortodoksie; Engelbrecht 1953: 317). Verdere getuienis van hoe sterk hy hierdie tweede aspek uitgebou het, is sy boek Neo-Calvinisme (1945). Die feit dat Engelbrecht so sterk met Obbink kon identifiseer (vgl sy waardering vir hom in Engelbrecht 1942: 62), hang ongetwyfeld saam met Obbink se belangstelling in die Afrikaners en in die besonder in die Hervormde Kerk alhier, waarvan onder andere sy hulp by die beroeping van predikante getuig. Dit klop ook met die feit dat die Afrikanersaak, veral die onafhanklikheidstryd teen Brittanje, simpatieke aandag by talle etiese teoloë gekry het en meermale in die etiese tydskrif Stemmen voor Waarheid en Vrede ter sprake gebring is.

Hier moet nog 'n nota bygevoeg word oor die Hervormers se houding teenoor die Neo-Calvinisme in die konteks van die teologiese opleiding. Soos ons reeds gesien het, was 'gereformeerdheid' altyd onaanvaarbaar. Dit was een van die twee pole waarteen die Hervormde teologie homself altyd afgegrens het en spreek eenduidig, in die konteks van ons ondersoek, van Goddefroy se optrede in 1890 verder. Engelbrecht se studie van en skerp kritiek op die gereformeerde teologie toon hoe langdurig dit deurgewerk het. Daar is wel hier en daar genoem dat 'landszonen' by die Gereformeerde Teologiese Skool te Potchefstroom kon inskakel (interessant genoeg het Engelbrecht self in 1912 daar ingeskryf, maar slegs die literêre lesings gevolg voordat hy na Nederland is), maar dit was altyd 'n periferiese klank en het nooit 'n ernstige moontlikheid geword nie. Daar was egter ook nie 'n animositeit teenoor die Dopper-Gereformeerdes nie aangesien die Gereformeerde afskeiding van 1859 nie met die bitterheid gepaard gegaan het wat kenmerkend van die latere tweespalt in die verhouding Hervormd/Kaaps was nie. Dit is merkwaardig, want die afskeiding van 1859 het die Hervormde Kerk ten spyte van die broederlike verhoudinge prinsipieel 'n valse kerk verklaar - iets wat nooit deur die Kaapse of verenigde kerk gedoen is nie. Dit toon vanuit 'n ander perspektief hoe seer kerkpolitieke en politieke oorweginge verhoudinge op ander gebiede, insluitende die opleiding, bepaal het (die Doppers en die Hervormers was die sterkste ondersteuners van die Krugerparty in die ZAR, wat verwag kan word as die president 'n Dopper en die vise-president 'n stoere Hervormer was). Daardeur word ook indirek bevestig dat die kerkpolitieke en politieke onderstrome inderdaad van primêre betekenis was by die ontwikkeling van teologiese strome in Transvaal, en dat ons vroeëre bevindinge ten opsigte hiervan nie ver van die kol is nie.

Vyf jaar ná Engelbrecht, in 1926, is dr B Gemser as professor aangestel. Hy was 'n leerling van twee van die leidinggewende etiese teoloë in Nederland, naamlik 
LHK Bleeker (die opvolger van Gerrit Wildeboer in Groningen) en FMTh de Liagre Böhl (sy promotor in Groningen). Self was hy waarskynlik een van die mees tipiese verteenwoordigers van die etiese rigting. Dieselfde geld van die ander Nederlander wat hom in 1938 by die geledere van die Hervormers in Pretoria kom voeg het, dr A van Selms wat sowel vir Semitiese tale as in die Fakulteit Teologie aangestel is. Hy was weer 'n leerling van Obbink te Utrecht en het hom tot aan die einde van sy lewe in 1984 bewustelik met die etiese rigting geïdentifiseer (vgl Loader 1984: 210). In die lewenswerk van beide Gemser en Van Selms vind ons die tipiese kenmerke van hul etiese vakgenote en voorgangers: 'n Indringende kritiese sin, handhawing van sowel die historiese kritiek (teenoor die 'orthodoxie') as die kerklike belydenis (teenoor die vrysinnigheid), 'n aversie aan dogmatisme maar waardering vir kerklike verbondenheid. Beide se invloed op die opleiding van Hervormde predikante sou oor jare strek - Gemser s'n direk tot 1957, toe hy 'n opvolger van Wildeboer, Bleeker en Vriezen in Groningen geword het, en indirek deur sy wêreldbekende publikasies ook daarna, en Van Selms s'n direk deur sy doseerwerk tot ná sy emeritaat in 1971 (sic) en sy ewe bekende publikasies.

In 1935 is dr HP Wolmarans as lektor aangestel en in 1938, toe Van Selms en dr CH Rautenbach as lektore bygekom het, het hy professor geword. Wolmarans het in 1932 te Groningen gepromoveer oor Die mens naar die beeld van God en het daar ook die invloed ondergaan van Bleeker en ander teoloë van die 'derde opsie' soos J Lindeboom. Voor dié tyd is hy in Pretoria opgelei deur Greyvenstein en Engelbrecht. Dit is daarom nie verbasend nie dat ons in sy proefskrif ' $n$ afwysing vind van die invloed van die idealistiese filosofie op die teologie (bv Wolmarans 1932: 194-195), maar ook dankbare gebruikmaking van die resultate van die historiese kritiek (bv Wolmarans 1932: 8-23). Ook hy het tot aan die einde van sy loopbaan die fundamentalisme afgewys.

Dr Rautenbach het in die filosofie gespesialiseer maar was nogtans betrek by die opleiding van predikante. Hy het as dosent en later ook as rektor dieselfde tradisie waarmee ons hierbo in aanraking gekom het, uitgebou. Daarvan getuig sy bydraes oor sake soos die Gewetensklousule, die doseer van die Bybel op universiteit en verwante sake (bv Rautenbach 1973: 31-36; 1974: 15-30), waarin hy ook na twee kante afgrens, naamlik die gereformeerde en die liberale.

Prof MacMillan het in 1933 bedank en is in 1935 opgevolg deur prof GM Pellisier van die NH of G Kerk. Dit het gebeur nadat die sinode van die 'Ofkerk' in 1934 daarvoor gevra het sodat hulle studente ook daar opgelei kon word. Hierdie versoek, wat nogal verskil het van ds HS Bosman se 'onvriendelikhede' wat 'n kwarteeu tevore teen 'n Pretoriase opleiding uitgespreek is (Engelbrecht 1953: 368), het in 1938 werklikheid geword toe twee outonome afdelings van die teologiese 
fakulteit tot stand gekom het. Bosman het die Hervormde bepleiters van 'n eie opleiding in Pretoria in 1909 'raddraaiers' genoem (sien De Hervormer 15 Julie 1909: 8 ). Presies 'n kwarteeu later het die rad met $180^{\circ}$ gedraai. Vandaar die bynaam 'Gatjieponders' vir die 'Ofkerk' - wat niks te doen het met die volksetimologiese herleiding tot manelbaadjies nie, maar ontwikkel het uit ' $n$ vervriendeliking van die Hervormde respons op die Bosmensiese 'raddraaiers'.

\section{KONKLUSIE}

Hierdie ondersoek dui daarop dat die tipies Hervormde karakter van die opleiding aan die teologiese fakulteit in Pretoria ontwikkel het uit die sameloop van 'n aantal historiese faktore.

Die eerste hiervan was die onafhanklikheidsin van die Transvaalse Afrikaners. Die vrees vir verlies van hul politieke onafhanklikheid, wat sy grond inderdaad in reële ervarings gehad het en verstaanbaar is by die kinders en kleinkinders van die Voortrekkers, het die vrees vir kulturele en religieuse ondermyning geïnkorporeer. Vandaar die teenkanting teen Stellenbosch, wat koloniaal en 'Engels' was. Vandaar ook die teenkanting teen die vereniging met die 'Kaapse Kerk'.

Hierdie politieke moment het natuurlikerwys beteken dat ' $n$ eiesoortige opleiding van predikante nodig was, want, as staatkundige onafhanklikheid gepaard moes gaan met kerklike onafhanklikheid, dan moes die kerklike leiers onafhanklik gevorm word.

Wat sou so 'n opleiding moes behels? - Dit sou on-Stellenbosch, dus onKaaps en on-gereformeerd moes wees. Dit sou ook afwysend moes staan teenoor die bevindelikheid van die piëtistiese tendens wat gedurende die periode van die kerkvereniging met die gereformeerde karakter van die Kaapse Kerk geassosieer is.

Waar sou dit te kry wees? - Dit sou of in Pretoria of in Nederland moes wees. Aangesien daar in Nederland ' $n$ Hervormde, dus on-gereformeerde, tradisie bestaan het, was dié die natuurlike aansluitingspunt solank dit prakties nie moontlik was om eie studente in Pretoria op te lei nie.

Die kerklike en teologiese situasie in Nederland het gedurende hierdie hele periode die skakerings vertoon van drie groot sfere: Die modernistiese of liberale of vrysinnige sfeer, die 'orthodoxe' of gereformeerde sfeer, en 'n sfeer tussen die twee wat moeilik van 'n etiket voorsien kan word (vgl die tipering van die tydgenootlike kerkhistorikus, J Lindeboom, 1916: 821, wat ook drie groot sfere met hulle onderstrominge onderskei, sy dit dan met ander name). In hierdie derde groep moet ons dié teologieë en teoloë tuisbring wat tot 'n wye skakering van 'rigtings', modaliteite of gesindes behoort het. Wat hulle wel in gemeen gehad het, was dat hulle net 
soseer teen die gereformeerde opvatting van dogma en belydenisskrifte standpunt ingeneem het as teen die modernistiese. Vanweë die feit dat sowel die liberale vrysinnigheid as die gereformeerde ortodoksie vir die Transvaalse Hervormers onaanvaarbaar was, het hulle vanselfsprekend in hul assosiasie met Nederland by die veelkleurige 'derde opsie' aansluiting gevind - veral by dié groeperinge daarbinne waar die piëtisme en bevindelikheid van die 'evangeliese rigting' nie teenwoordig was nie.

Aangesien die 'derde opsie' ook die tuiste was van die etiese teoloë, is dit begryplik dat die Hervormers predikante sou beroep wat deur die etiese teologie beinvloed was (bv ds LE Brandt), dat professore van etiese inklinasie onder hul leermeesters sou tel (vgl die keuse van Van Drimmelen, Fourie, Vermooten, Greyvenstein, Engelbrecht en Wolmarans), en dat hulle hul geledere sou versterk met hulp uit dieselfde oord (getuige die hulp van Obbink en die koms van Gemser en Van Selms). Dit is des te meer begryplik aangesien die etiese teologie alles kon bied wat vir Hervormers belangrik was: distansie van die gereformeerde teologie, afwysing van die bevindelikheid van die 'evangelischen' (vgl Valeton se kritiek hierop, uitgewerk in sy bespreking van die verskillende rigtings en die standpunt van die etici daarteenoor; Valeton 1909), en tegelyk 'n regsinnigheid wat standpunt teen die liberale teologie ingeneem het. In hierdie kategorie val ook die rol van PJ Muller, wat, al kan hy nie in die gebruiklike sin van die woord 'n etiese teoloog genoem word nie, tog in die 'derde opsie' tuisgehoort het.

Daarom moet verwag word dat die Hervormde teologie, soos bedrywe aan die fakulteit te Pretoria, die karakter van die 'derde opsie' en meer bepaald dié van die etiese teologie sou vertoon. Die hele sturigting van die geskiedenis tendeer daartoe en dit sou juis verbasend wees as dit nie die geval was nie. As al vier sy eerste professore onder etiese teoloë gestudeer het, en/of noue bande met hulle behou het, en/of self onder die vooraanstaande etiese teoloë getel het, kan dit kwalik anders verwag word.

Waarom hierdie oriëntering so lank verwaarloos of onderbeklemtoon is, is verklaarbaar deur die feit dat die 'derde opsie', anders as die modernisme en die 'orthodoxie', veelgeskakeerd en allesbehalwe ' $n$ sluitende sisteem was. Dit geld ook vir die etiese teologie wat 'n belangrike fokuspunt binne hierdie sfeer was. Die etiese teoloë het juis wal gegooi teen die opvatting dat hulle 'r. sisteem verdedig (vg) Valeton 1883: 15-16) en het self ook die ontrekbaarheid van die grense van 'n etiese party uitgewys (Valeton 1909: 6.7). Dit het meer gegaan om 'n benadering as om 'n sisteem of 'n party. Daarom was die etiese invloed nooit so maklik identifiseerbaar en etiketteerbaar soos die modernisme, gereformeerde ortodoksie of konfessionalisme nie. Soos die modernisme het hulle die Skrifkritiek hoog aangeslaan en be- 
oefen, soos die ortodoksie het hulle waardering vir die dogmata van die kerk gehad, soos die konfessionalisme het hulle die belydenis van die kerk gehandhaaf; maar anders as die modernisme het hulle die kategorie openbaring hoog geag (die uitstaande kenmerk van HP Wolmarans se Groninger dissertasie), anders as die ortodoksie het hulle 'n oorwaardering van die dogma afgewys (Loader 1984: 17-20), anders as die konfessionalisme was hulle bedag op die oorbeklemtoning van die belydenisskrifte ten koste van 'n lewende geloof, en anders as die evangeliese stroming het hulle teen bevindelikheid wal gegooi. Dit is die rede waarom hulle so fel van links en van regs aangeval is. Vir die een groep was hulle te konserwatief en vir die ander die toonbeeld van liberalisme. Ons sal alleen kan sê dat 'die etiese teologie' nie bepalende invloed in die Hervormde Kerk alhier gehad het nie as ons onder 'eties' iets verstaan wat alleen kortstondig in die twintiger- en dertigerjare van hierdie eeu bestaan het, naamlik 'n vasomlynde, gekonstitueerde groep of vereniging. Dit is egter foutief om hierdie groep as die bril te neem waardeur ons na die etiese beweging of suurdeeg van die negentiende en vroeë twintigste eeu kyk, want die etici het prys gestel daarop dat die lewensbeginsel van hul teologie juis daardeur geweld aangedoen sou word (vgl Loader 1984: 15). 'n Soortgelyke opvatting oor die invloed van die etici is daarop nagehou deur die Groninger kerkhistorikus uit die periode wat ons hier interesseer en leermeester van HP Wolmarans en andere, J Lindeboom (1916: 855-856). Volgens hom was die kerklike invloed van die etiese teoloë beperk vanweë die genuanseerdheid daarvan. Op teologiese gebied sowel as op algemeen religieuse gebied (dws op die terrein van die geloofsbelewing en beantwoording van kontemporêre religieuse vrae eerder as op kerkregtelike en organisatoriese gebied) was hul invloed egter enorm. Hulle het selfs op die gebied van die kritiese Bybelwetenskap in produksie en in invloed begin om 'de modernen achter zich te laten' (Lindeboom 1916: 856).

Hier het ons myns insiens die verklaring vir die wyse waarop die etiese invloed in die plaaslike Hervormde teologie deurgewerk het sowel as vir die persepsie van die Hervormde teologie by homself en by andere in Suid-Afrika. In die eerste plek het die etiese teologie sy invloed incognito uitgeoefen (vgl Loader 1987: 48). Omdat daar geen vereniging, kerklike strategie of sluitende sisteem was nie en omdat die grense van die beweging per definisie vaag was, was daar ook nie 'n maklik herkenbare vlag waaronder die skip geïdentifiseer kon word nie. Daarom is die invloed van die etiese teologie makliker gelees in terme van dit ten opsigte waarvan hy met ander rigtings oorvleuel. Dit gaan nie soseer om 'invloed' in die sin van organisatoriese 'suksesse' en groepvorming nie, maar wel om 'n gees, 'n benadering. Vandaar dat die Hervormde teologie so lank reeds hier te lande vanuit gereformeerde oord as liberaal bestempel word (vgl Die Burger, 4 November 1936, 
waar berig word oor die bespreking van die vorige dag op die sinode van die Kaapse Kerk oor die begeerte van die 'Ofkerk' om saam met die Hervormers 'n kerklike opleiding in Pretoria te hê - die 'kerk in die noorde' sou nou in liberale geselskap kom). Dit is presies wat aan die einde van die vorige en die begin van hierdie eeu deur gereformeerdes in Nederland van die etiese teologie gesê is (vgl Loader 1987: 47-48). Aan die ander kant reageer Hervormers altyd skerp afwysend teen hierdie beskuldiging, maar - selfs in die geval van 'n deurwinterde historikus soos SP Engelbrecht - dikwels sonder berekening van die historiese agtergrond vir die beskuldiging en die weerlegging. Omdat hy met openbaring werk en die belydenis nie wil minag nie, kan die Hervormde teologie, dié slag beoordeel vanuit modernistiese perspektief, ewe goed as behoudend getipeer word.

Die etiese teoloë het bewustelik angesluit by die Switser, Alexandre Rodolphe Vinet (1797-1847), 'n verteenwoordiger van die tendens om die rasionalisme sowel as die kerklike ortodoksie af te wys. Dit was tipies van die kringe wat onder die impak van Friedrich Schleiermacher gestaan het. Hoewel die etici nie direk deur Schleiermacher beïnvloed was nie en op sommige punte (bv die evaluering van die Ou Testament) van hom verskil het, is hulle, soos talle strominge in die negentiende-eeuse teologie, wel middellik deur hom beinvloed. Hulle toon duidelik die kenmerke van 'n teologie wat nòg die rasionalisme (van die modernisme) nòg die kerklike ortodoksie (van die gereformeerde kringe) kon aanvaar. As ons dit nou in verband bring met die Hervormers van die ZAR se kerklik-teologiese aansluiting by Nederland in bewuste opposisie teen Stellenbosch, is die karakter van die teologiese oriëntering wat hieruit gegroei het goed verstaanbaar. Sowel die 'Engelse' aspek van die Skotse invloed in 'Stellenbosch' ( = die Kaapse Kerk) as die gereformeerdheid van 'Stellenbosch' sou vanselfsprekend afgewys word. Dit is presies wat gebeur het. Vandaar dat die sogenaamde 'Scottish common sense realism' geen plek in die Hervormde teologie kon verower nie en dat daar ewe min plek vir die gereformeerde ortodoksie van Kuyperiaanse huise kon wees. Die Skotse 'realisme', wat die openbaring van God en die getuienis daaraangaande direk geïdentifiseer het, het kop-aan-kop gebots met die diepste wese van die etiese teologie en ewe tromp-op met die Hervormde teologie. Daarom kon daar nooit 'n vastrapplek vir die fundamentalisme, wat uit die 'common sense'-teologie ontstaan het, in die Hervormde teologie gevind word nie. Om dieselfde rede kon die invloed van Kuyper en kie, wat wel nie deur ' $n$ 'common sense' nie maar deur ' $n$ idealistiese Skrifbeskouing geïnspireer was, geen duik op Hervormers maak nie. Of die wortel nou 'realisties' of 'idealisties' heet, in die praktyk het die Skotse 'common sense' sowel as die gereformeerde Skrifbeskouing 'n on- en anti-kritiese Skrifbeskouing gevoed. Dit het in die Kaapse Kerk inslag gevind omdat die twee voedende tradisies 
daarvan daar inslag gevind het. Nie een het in die Hervormde teologie inslag gevind nie omdat die tradisie wat die Hervormde teologie gevoed het, wesenlik teenoor hulle gestaan het.

'n Nota sou hier bygevoeg kon word oor die Afrikaner-nasionalisme wat in die Transvaalse Hervormerkringe vis- $\boldsymbol{d}$-vis die Kaapse gereformeerde kringe voorgekom het. Laasgenoemde het van huis uit sy tuiste in die gereformeerde Kuyperianisme, wat op sy beurt weer geïnformeer is deur die idealistiese staatsidee van Fichte, terwyl eersgenoemde geensins hierdeur beïnvloed is nie. Die Transvalers was ten opsigte hiervan naief en het hul nasionalisme ontwikkel uit 'n eenvoudige begeerte tot onafhanklikheid en handhawing van hul identiteit as Afrikaners teenoor Engelse en as blankes teenoor swartes. Hoewel die grondliggende faktor, naamlik beskerming van eie belange, by Kapenaars en Transvalers dieselfde was, was die oorsprong en stukrag van die twee nasionalismes verskillend. Dit het nog lank deurgewerk, soos gesien kan word in die heftige animositeit van SP Engelbrecht teenoor DF Malan. Malan het byvoorbeeld, gedurende sy studie in Nederland, in briewe aan die pers (wat nie destyds gepubliseer is nie) probeer om die persepsie in Nederland oor die Hervormde Kerk as 'ware Boerekerk' teen te gaan en hierdie eer vir die Kaapse Kerk probeer opeis. Engelbrecht se aantekeninge in die argiefstukke waar hierdie en verwante dokumente bewaar word, laat geen twyfel oor die kerklik-teologiese verwyderdheid van die twee soorte Afrikanernasionalisme nie. Dit bring ons by die laaste punt wat hier onderstreep moet word, die laaste stuk van die legkaart wat myns insiens, soos al die ander, ook in posisie val.

Dit is dat die historiese agtergronde van die Hervormde teologiese opleiding ook verklaar waarom die vir baie onbegryplike situasie ontstaan het dat die Hervormde Kerk kan geld as 'n tuiste vir polities konserwatiewe sentimente en tegelyk teologies ' $i$ beraal' kan voorkom. Die een kant van die antwoord is dat die presipiterende faktor by die strewe na 'n eie opleiding en dus ' $n$ eie teologie polities van aard was en stam uit die onafhanklikheidsin van Transvaalse Boere. Hierdie tradisie het nooit verdwyn nie. Die ander kant van die antwoord is dat die kombinasie van 'n kerklike sin en waardering vir die Skrifkritiek deur die ontmoeting met die etiese teologie die opleiding en dus die teologie binnegekom het vanuit die histories bepaalde kontak tussen Transvaal en die 'derde opsie' in Nederland. Indien nie hieruit nie, waanit dan? Ook hierdie tradisie het nooit verdwyn nie. Laat ons bid dat resente ontwikkelinge op politieke terrein nie sal veroorsaak dat 'n teologie ontwerp word wat moet dien as hulp wat daarby pas nie. Dit sou die Hervormde tradisie nie bewaar nie maar juis begrawe.

Vivat, crescat, floreat Van der Hoff? 


\section{Literatuurverwysings}

Aangesien in hierdie studie heelwat gesteun is op materiaal uit die notules van die Algemene Kerkvergadering en ook uit dié van die Volksraad van die ZAR, sowel as op korrespondensie wat dikwels anoniem en onder voorletters in die pers verskyn het, word die volgende verwysingsisteem hier gebruik:

1. In die teks word na die genotuleerde bronne verwys deur in hakies die woord 'Notule' plus die bladsynommer te verstrek, of, in die geval van die Volksraadsnotules, die besluitnommer; die konteks dui telkens aan watter jaar se vergadering bedoel word. Verwysings na briewe in die pers word as deel van die teks gehanteer.

2. Ander literatuur:

BOTHA, SJ 1977. Ds Marié Joseph Goddefroy. Almanak 71, 19-23.

BOTHA, SJ 1987. Ds MJ Goddefroy en Christelik-nasionale onderwys. HTS 43/12, 57-71.

ENGELBRECHT, SP 1927. Het ontstaan van de opleiding onzer predikanten. Almanak 21, 194-207.

ENGELBRECHT, SP 1942. Eeufees-Album van die Nederduitsch Henormde Kerk van Afrika 1842-1942. Pretoria: Wallachs.

ENGELBRECHT, SP 1945. Neo-Calvinisme; ontwikkeling en afwyking, 'n woord van verweer. Pretoria: De Bussy.

ENGELBRECHT, SP 1953. Geskiedenis van die Nederduitsch Hervormde Kerk van Afrika. Pretoria: De Bussy.

GODDEFROY, MJ 1890. De kerkkwestie: Niet een leer- maar een levenskwestie. Pretoria: Volksstem.

GREYVENSTEIN, JHJA 1911. Het sociale utilisme van Bentham. Utrecht: Oosthoek.

LINDEBOOM, J 1916. Geschiedenis van de Hervorming en de Hervormde Kerk der Nederlanden. 3. uitg. Utrecht: Kemink.

LOADER, JA 1984. Die etiese Ou-Testamentici in Nederland tussen 1870 en 1914. Diss Pretoria 1984.

LOADER, JA 1987. Tertium datur - oor die etiese waarheidsbegrip. HTS $43 / 1$ en 2, 47-57.

MULLER, PJ 1895. Handboek der dogmatiek ten dienste der Hervormde Kerk. Groningen: Wolters.

MULLER, PJ 1898. De Godsleer der Middeleeuwsche Joden. Groningen: Wolters.

PRINSLOO, JJ 1911. Onze kweekschool. Almanak 5, 73-75. 
RAUTENBACH, CH 1973. Gewetensklousule bly twisappel in Nasionale Onderwys. Almanak 67, 31-36.

RAUTENBACH, CH 1974. Nasionale onderwysopleiding; die Bybel op universiteit - Ja, maar hoe? 'n Voorwoord. Almanak 68, 15-30.

VALETON, JJP jr 1883. Geloof en theologie. Utrecht: Kemink.

VALETON, JJP jr 1909. De ethische richting. Baarn: Hollandia.

WOLMARANS, ADW s a. Kerkhistorische feiten: Bijdrage tot de kennis van de geschiedenis der Ned Herv Kerk in Zuid-Afrika. Pretoria: De Bussy.

WOLMARANS, HP 1932. Die mens naar die beeld van God. Purmerend: Muusses. 